\title{
Örgütsel Sessizliğe Dair Kavramsal Bir İnceleme a
}

\author{
Gamze Macit ${ }^{\mathrm{b}, \mathrm{c}}$, Ramazan Erdem ${ }^{\mathrm{d}}$
}

\section{Özet}

Örgütsel sessizlik, bir konu veya sorun karşısında, çalışanların itaat, korku ve iş birliği güdüleri ile hareket ederek, bilgi, duygu ve düşüncelerini kasitlı olarak paylaşmamaları olarak tanımlanabilir. Örgüt içinde bir tepki göstergesi olarak kabul edilen, içinde birçok duyguyu barındıran, örgütsel ve bireysel nedenlerle ortaya çıkan örgütsel sessizlik kavramı son yıllarda önem kazanmaya başlamıştır. Örgütsel sessizlik, önlem alınmadı̆̆ 1 takdirde hem çalışanlar hem de örgütler üzerinde birçok olumsuz etkiye neden olur. Yöneticilerin, örgütsel sessizlik nedenlerini ortadan kaldırarak, çalışanların her durumda bilgi, duygu ve düşüncelerini korkmadan ifade edebilecekleri bir örgüt yapısı oluşturmaları ve örgütsel sessizliğin örgüt içinde yaygın bir kültür haline gelmesini önlemek için çaba sarf etmeleri oldukça önemlidir. Bu çalışmada, örgütlerin büyük bir çoğunluğunda rastlanan ancak önemi gözardı edilen örgütsel sessizlik kavramının kapsamlı bir tanımı yapılarak, örgütsel sessizliğin tarihsel gelişimi, nedenleri, türleri ve etkilerinden detaylı olarak bahsedilmiştir. Örgütsel sessizlik hakkında teorik bilgilerin verildiği bu çalışma gelecekteki çalışmalara da katkı sağlayabilecektir.
Anahtar Kelimeler

Örgütsel Sessizlik

Kabullenici Sessizlik

Savunma Amaçlı Sessizlik

Koruma Amaçlı Sessizlik

Makale Hakkında

Geliş Tarihi: 13.03.2019

Kabul Tarihi: 10.06.2020

Doi: 10.18026/cbayarsos.539307

\section{A Conceptual Review on Organizational Silence}

\begin{abstract}
Organizational silence can be defined as the fact that employees act with obedience, fear and cooperation motives in the face of a subject or problem and do not deliberately share their knowledge, feelings and thoughts. The concept of organizational silence, which is considered as a response indicator within the organization and contains many emotions and emerges for organizational and individual reasons, has started to gain importance in recent years. Organizational silence causes many negative impacts on both employees and organizations unless measures are taken. It is very important for managers to eliminate the causes of organizational silence, form an organizational structure in which employees can express their knowledge, feelings and thoughts without fear and make efforts to prevent organizational silence from becoming a widespread culture within the organization. In this study, a comprehensive definition of the concept of organizational silence which is found in the majority of organizations, but whose importance is ignored, is explained and the historical development, causes, types and effects of organizational silence are discussed in detail. This study provides theoretical information about organizational silence, may contribute to future studies.
\end{abstract}

Keywords

Organizational Silence

Acquiescent Silence

Defensive Silence

Prosocial Silence

About Article

Received: 13.03 .2019

Accepted: 10.06 .2020

Doi: $10.18026 /$ cbayarsos.539307

\footnotetext{
a Bu çalışma Gamze Macit'in Prof. Dr. Ramazan Erdem'in danışmanlığında hazırladığı “Örgüt Kültürü ile Örgütsel Sessizlik Arasındaki İlişkilerin İncelenmesi" isimli doktora tezinden üretilmiştir.

b İletişim Yazarı: gamzemacit@hotmail.com

c Dr., Burdur Çevre ve Şehircilik İl Müdürlüğü, ORCID numarası: 0000-0001-6003-8738

d Prof. Dr., Süleyman Demirel Üniversitesi, İ̈BF, Sağlık Yönetimi Bölümü, ORCID numarası: 0000-0002-5986-8280
} 


\section{Giriş}

Örgütlerin, değişimin çok yoğun bir şekilde yaşandığı rekabet ortamına uyum sağlayabilmeleri ve yaşamlarını sürdürebilmeleri için ihtiyaç duyduğu en önemli faktör insandır. Teknolojinin gelişmesi ile birçok sorunun üstesinden gelinebileceği düşünülse de, bir örgütün başarısı, örgütün en önemli unsuru olan insana verilen değer ile yakından ilgilidir. Çünkü gerekli bilgilere ve deneyimlere sahip çalışanlar örgüt içinde önemli bilgi kaynaklarıdır. Örgütte karşılaşılan sorunların çalışanlara yansıması ve onların örgütle uyum içinde olmamaları durumunda, örgütlerin amaçlarına ulaşmasındaki en büyük engellerden biri ile karşılaşılmış olacaktır.

Çalışanlar için her açıdan kusursuz bir iş ortamı oluşturulsa bile, çalışanlara gereken önem verilmediği takdirde örgütlerin başarıya ulaşmaları mümkün değildir. Çalışanların verimliliklerinin arttırılabilmesi ve örgütün başarıya ulaşabilmesi için çalışanların her koşulda söz sahibi olabilmesi, olumsuz durumlar karşısında bile fikir ve düşüncelerini korkusuzca ifade edebilmesine imkân tanınması gerekir.

Çalışanların sessiz kalmayı tercih etmesi nedeniyle onların uyum içinde çalıştıkları düşüncesi geçerliliğini kaybetmiştir. Örgütsel sessizlik son yıllarda önem kazanmaya, sessizlik bir "uyum" göstergesi olarak değil "tepki" göstergesi olarak kabul edilmeye başlamıştır. Örgütlerin sahip oldukları bilgiyi paylaşmaktan ve risk almaktan korkmayan çalışanlara daha çok ihtiyacı vardır. Örgütlerde, şikâyetçi olarak görünmemek, yönetimin bilgi paylaşımını desteklemeyen bir yapıda olması, korku gibi çeşitli nedenlerle sessiz kalmayı tercih eden, kasıtlı olarak bilgi ve görüşlerini ifade etmekten kaçınan çalışan sayısının artığı düşünülmektedir.

Bu çalışmanın amacı, örgütsel sessizlik kavramını teorik olarak inceleyerek, tarihsel gelişimini, nedenlerini, türlerini, olumsuz etkilerini ve alınabilecek önlemleri ortaya koymaktır. Bu amaç doğrultusunda örgütsel sessizlik kavramı ile ilgili literatür incelenerek konunun teorik çerçevesi çizilmeye çalışılmıştır.

\section{Örgütsel Sessizlik}

Örgütsel sessizlik konusunda önemli çalışmaları bulunan Morrison ve Milliken (2000)'e göre örgütsel sessizlik, çalışanların örgütsel konularla ya da sorunlarla ilgili görüş ve fikirlerini açıkça ifade etmeyerek kendilerine saklamasıdır. Kolektif düzeyde bir fenomen olan örgütsel sessizlik, çalışanlar arasındaki farklılıkları değerlendiren ve yansıtan, birden fazla perspektif ve görüşlerin ifadesine izin veren çoğulcu örgütlerin gelişmesinde önemli bir engel oluşturabilir. Örgütsel sessizliğin nedenlerini izleyip anlayarak, örgütlerde çoğulculuğa ilişkin engellerin doğru ve kapsamlı bir şekilde anlaşılması sağlanabilir (Morrison ve Milliken, 2000: 706 -707).

Adaletsizliğge bir tepki olarak ortaya çıkan örgütsel sessizlik, örgüt üyelerinin örgütsel koşullar ile ilgili davranışsal, bilişsel ve duygusal değerlendirmelerini, bu durumu etkileyecek ya da düzeltebilecek kişilere bilerek ve isteyerek söylememesidir. Örgütsel sessizliğin ortaya çıkması için, koşulları değiştirme isteğinin olmaması veya bu koşulları iyileştirme kabiliyetine sahip olan kişilerle iletişimin olmaması gerekir (Pinder ve Harlos, 2001: 334).

Sessizlik kavramı birçok yönetim bilimi kavramında olduğu gibi yüzeysel anlamda kolay tanımlanabilecek ve analiz edilebilecek bir yapıda gibi görünmektedir. Oysaki oldukça 
karmaşık ve bağıntılı bir yapısı bulunmaktadır (Öztürk ve Cevher, 2016: 72). Çoğunlukla suskunluk ve uyumla aynı olduğu süşünülerek, özellikle toplumumuzda uygun bulunup desteklenen, hatta "Söz gümüşse, sükût altındır." gibi atasözleri ile kültürümüze bile işleyen bir kavramdır (Eroğlu vd., 2011: 99). Örgütsel sessizliğin hâkim olduğu örgütlerde, çalışanlar, değişimin güçlü ve önemli bir kaynağı olmalarına rağmen çoğunlukla sessizliği tercih etmektedirler (Bowen ve Blackmon, 2003: 1394). Birçok örgütte yöneticiler, çalışanların sadece bazı görüşlerini ifade etmelerini desteklemektedir ve sınırlı seviyede iletişim kurmalarına imkân tanımaktadır. Bütün görüşlerini açıkça ifade edemeyen çalışanlar ise bir süre sonra sessiz kalma davranışı sergilemeyi seçebilmektedir.

Örgüt üyeleri, bazı durumlarda mahçup olmamak ya da diğer örgüt üyeleri ile karşı karşıya gelmemek için sessiz kalmayı ve kendilerini rahat ifade edebilecekleri örgütleri tercih etmektedirler. Örgütsel sessizliğin hâkim olmadığı örgütlerde, yöneticiler ve diğer örgüt üyeleri daha yüksek motivasyon ve performansa sahiptir. Farklı görüş ve düşüncelere sahip insanlar bu farklılıklarla yüzleşmek istemedikleri zaman sessizlik ortaya çıkmaktadır. Örgütsel konular ile ilgili, örgüt üyelerinin büyük çoğunluğu sessizliğe büründüğünde, örgüt içinde kollektif bir sessizlik hâkim olur (Durak, 2012: 64-65). Örgütler kadar çalışanları da olumsuz etkileyebilen örgütsel sessizliğin hâkim olduğu kültürlerde, çalışanların sessiz kalmaları içinde bulundukları koşullardan memnun oldukları şeklinde algılanabilir. Ekonomik krizler, çalışanların işini kaybetme korkusu, sorunlu ve dedikoducu biri olarak algılanma korkuları, bulundukları koşullardan memnun olmamalarına rağmen çalışanların sessizliği tercih etmesine yol açabilir (Demir ve Demir, 2012: 185; Kahveci ve Demirtaş, 2013: 52-53).

Örgütsel sessizlik, örgütlere nüfuz eden, yaygın olduğu halde hakkında nispeten az akademik araştırma bulunan, genellikle araştırmacılar tarafından ihmal edilen, basit görülen ve hak ettiği değeri görmeyen bir kavramdır. Sessizlik konusuna çok az ilgi gösterilmesinin iki nedeni vardır. Birincisi, sessizliğin "konuşmanın yokluğu” olarak görülmesidir, konuşma gerçekleşmediğinde, davranış yokluğu özellikle belirgin değildir ve dikkat çekmez. İkincisi bu ilk neden ile ilgili olarak, daha açı ve daha belirgin bir davranışa göre bu davranış eksikliğinin araştırmanın daha zor olmasıdır (Van Dyne vd., 2003:1363-1364).

Örgütsel sessizliğin kendi içinde çelişkili, sübjektif ve karmaşık bir yapısı vardır fakat bu karmaşıklık ve irrasyonelliği içinde kendine has bir ahengi ve sınırlı bir rasyonelliği bulunmaktadır (Öztürk ve Cevher, 2016: 72). Jensen (1973)'e göre, sessizliğin; insanları bir arada tutma ya da uzaklaştırma, insanlar arasındaki ilişkilere zarar verme ya da bu ilişkileri düzeltme, bilgi sağlama ya da bilgileri gizleme, derin düşüncelerin varlığ1 ya da düşünce yolkuğunun olması, insanları hem kabul etmeye hem de reddetmeye yöneltme gibi işlevleri vardır (Akt: Pinder ve Harlos, 2001: 338).

Örgüt ortamlarında sessizliği ve sesi anlamada esas teşkil eden temel süreç “yayılma” fikridir. Başka bir deyişle, bir konuda sessizlik olarak başlayan şey, bir dizi konunun sessizliği için yayılabilir, bir konuyla ilgili sessiz kalma kararı, diğer konularda sessizliğin artması olasılığına neden olur. Özellikle kişisel önemi olan bir konudaki sessizlik yayılabilir, çünkü bir kişinin örgütteki diğer insanlarla olan bağlarının gücünü etkiler, diğerlerinden bilinçli olarak bilgi kesintisi ile bağlar zayıflar, bu zayıflamış bağlar, güven düzeyinde bir bozulma ve diğer konularda konuşma ihtimalinin azalmasına neden olur (Milliken ve Morrison, 2003: 1564). Bilgi ve fikirlerin saklanması, örgütsel karar verme, hata düzeltme-geliştirme ve yenilik süreçlerini zayıflatabilir (Vakola ve Bouradas, 2005: 443). Genel olarak, örgütsel sessizlik, 
çalışanlar tarafından bilgilerin kasıtlı olarak ifade edilmesinden kaçınmaları anlamına gelir ancak her iletişim dışı durum örgütsel sessizlik anlamına gelmemektedir. Örgütsel sessizlik, çalışanların söyleyecek birşeyleri olmamasından kaynaklanan iletişim eksikliğini değil, çalışanların bilgilerini ve görüşlerini kasıtlı olarak saklamalarından kaynaklanan iletişimsizlik durumunu kapsamaktadır.

\section{Örgütsel Sessizlik İncelemelerinin Tarihsel Gelişimi}

Örgütlerde ses ve sessizlikle ilgili yapılan araştırmalar incelendiğinde farklı anlayışları yansıtan üç dönemin öne çıktığ1 görülmektedir Kronolojik olarak ilk dalga 1970'lerden başlayıp 1980'lerin ortasına kadar olan dönemi; ikinci dalga 1980' lerin ortasından başlayıp 2000' lere kadar olan dönemi ve son olarak mevcut dalga 2000'lerden günümüze kadar gelen süreyi kapsamaktadır (Brinsfield vd., 2009: 4).

\section{İlk Dalga}

1970'den 1980'li yılların ortalarına kadar olan dönemi kapsamaktadır. Albert O. Hirschman'ın 1970'de yayımlanan "Exit, Voice and Loyalty" adlı eserinde çalışan sessizliği kavramı ilk kez tanımlanmaya çalışılmıştır. Hirschman (1970) sessizliği pasif fakat bağlılık (loyalty) ile eş anlamda kullanmış ve daha sonra da yönetim bilimciler sessizliği bağlılığa eşitlemeye devam etmişlerdir (Brinsfield vd., 2009: 8; Çakıcı, 2007: 149). İlk dalga döneminde, "mum (susma) etkisi" ve "sessizlik sarmalı" çalışmaları ile ses ve sessizlik sınıflandırılmaya çalışılmıştır (Brinsfield vd., 2009: 8).

MUM etkisi (mum about undesireable message /istenilmeyen mesajlar hakkında sessizlik); çalışanların, huzursuzluğa neden olacağından dolayı, olumsuz bilgileri iletme konusundaki genel isteksizlikleridir ve çalışanların örgütte karşılaşılan sorunlarla ilgili neden sessiz kaldıklarının olası bir açıklaması olarak değerlendirilmektedir. MUM etkisinin; kötü haberi iletmedeki huzursuzluk hissi, haberi veren ile alan arasındaki ilişkinin zarar görebileceği endişesi ve haber alanın talihsizliğini paylaşmamaktan kaynaklanan suçluluk duygusu gibi etkenler sonucunda oluştuğu gözlemlenmiştir (Rosen ve Tesser, 1970: 254). Örgütte, bireyler arasındaki statü ve güç farklılıkları da MUM etkisini kuvvetlendirmektedir. Bazı araştırmalar, çalışanların haksızlıklar ya da olası problemler hakkındaki kaygılarını üstlerine bildirirken huzursuz olduklarını ve karşılaşabilecekleri olumsuz etkilerden kaçınmak için bilgiyi sakladıklarını ya da çarpıttıklarını ortaya koymuştur. Bu etki sadece yukarı yönlü iletişim ile sınırlı değildir, aynı zamanda yöneticiler de kimi zaman geri bildirim almaktan kaçınabilirler ya da süreci geciktirebilirler (Brinsfield vd., 2009: 10-11).

Sessizlikle ilgili bir diğer önemli çalışma ise Elisabeth Noelle-Neumann (1974) tarafından ortaya atılan sessizlik sarmalı teorisidir. Neumann, bireylerin toplumun sorunları hakkında kendilerine desteğin zayıf olduğunu algıladıklarında sessiz kalma eğilimlerini koruduklarını, aksine toplumun daha güçlü desteği karşısında görüşlerini daha kendinden emin olarak ve korkmadan ifade edebildiklerini belirtmektedir (Akt: Brinsfield vd., 2009: 11). Sessizlik sarmalı, bireyin fikrini belirtmeden önce, fikrin kamu desteği düzeyini değerlendirme olayıdır. Kişiler kendi fikirlerini ve düşüncelerinin, örgütün genel düşüncesi ile uygun olması durumunda etkili olabileceğini düşündükleri takdirde fikirlerini açıkça ifade etme 
eğilimindedirler. Aksi durumda daha tedbirli davranarak sessiz kalmayı tercih edeceklerdir (Çakıcı, 2010: 17; Bowen ve Blackmon, 2003: 1394).

Bireyler, çoğunluğun fikrine uymadıkları için dışlanabilirler, hata yapma korkusundan daha çok yalnız kalma korkusu ve kabul görme ihtiyacı ile diğer insanlar ile aynı fikirde olmasalar da çoğunluğa katılmayı tercih edebilirler. Çoğunluk tarafından benimsenen görüş ile azınlıkta kalan görüşleri değerlendirmeleri sonucunda kişiler, fikrini söyleme ya da söylememe yönünde karar alırlar (Çakıcı, 2010: 17). Çalışanlar, iş arkadaşlarından destek bulmadıkça seslerini çıkartmayacaklardır. Eğer akranlarının desteğinden emin değillerse ya da sese karşı direniş olasılığ 1 yüksekse, sessizlik ya da dürüst olmayan bir yanıtı seçerler. Bu nedenle, ses ve sessizlik arasındaki tercih, büyük ölçüde bir çalışma grubundaki 'fikir iklimi' tarafından belirlenir. Çalışma grupları içindeki bu iletişim yaklaşımı, hâkim görüşün bir konudaki rolünün yanı sıra sosyal bütünlük, güven ve çalışma grubuna yönelik tutumu da vurgulamaktadır (Bowen ve Blackmon, 2003: 1394). Çalışanlar kendilerini azınlık olarak hissettiklerinde, yalnız bırakılma korkusu ile görüşlerini açılamada gönülsüz davranarak daha çok sessizliği tercih edeceklerdir. Buna karşın kendi görüşlerinin çoğunluk konumunda olduğunu hissettiklerinde ise sessiz kalmayıp konuşmayı tercih etme ihtimalleri daha fazladır (Durak, 2012: 65-66). Örgütün gelişimi için gerekli olan grup tartışmalarını, düşünce ve bilgi alışverişini, yeni fikir ve düşüncelerin ortaya çıkmasını engelleyen sessizlik sarmalının kırılarak, örgüt içinde yeni fikir ve düşüncelerin açıkça ifade edilebilmesini sağlamak gerekmektedir (Kahveci ve Demirtaş, 2013: 54).

\section{İkinci Dalga}

İkinci dalga, 1980'lerin ortasından başlayıp 2000'lere kadar olan dönemi kapsamaktadır. Bu süre içerisinde ses ve sessizlikle ilgili araştırmaların içeriği muhbirlik (sorun bildirme), ilkeli örgütsel muhalefet, konu benimsetme ve şikâyetçi olma gibi birkaç yeni yapıyı da kapsayacak şekilde genişlemiştir. Yine bu dönemde örgütsel vatandaşlık ve örgütsel adalet konuları araştırmalarda yerini almıştır. İlk defa 1987 yılında Greenberg tarafından kullanılan örgütsel adalet kavramı çalışanların konuşması yani sesliliği üzerine odaklanmıştır. Araştırmacılar, 1990'lı yılların sonuna doğru ise sessizlik ile bağlantılı sağır kulak sendromu ve sosyal dışlanma gibi konulara yönelmiştir (Brinsfield vd., 2009: 12; Durak, 2012: 46).

Örgütsel hareketsizlik olarak adlandırılan sağır kulak sendromu, çalışanların hoşnutsuzluklarını doğrudan ve açı bir şekilde ifade etmelerini cesaretlendirmeyen ortamlarda büyür ve bir örgütsel norm olarak ortaya çıkar. Böyle ortamlarda, 'duymadım', 'görmedim', 'bilmiyorum' stratejisi ile sessiz kalmak en kestirme yanit olur (Çakıcı, 2007: 157). Bir kişinin ya da grubun, diğer kişi ya da grubu görmezden gelmesi olarak tanımlanabilecek sosyal dışlanma ise sessizliğin yaygın bir biçimi olarak karşımıza çıkabilmektedir. Sosyal dışlanma, sadece kişinin başka bir kişiye karşı takındığı sessiz tutum ile değil, sözlü iletişim yetersizliğinden daha fazlası olarak, o kişiyi tamamen görmezden gelmesi ile ilgilidir (Williams, 2007: 429; Lustenberger ve Williams, 2009:246).

\section{Mevcut Dalga}

Mevcut dalga (current wave), 2000'lerden günümüze kadar gelen süreyi kapsamaktadır. Bu dönemde konuşma ve sessizlikle ilgili araştırmalar artmıştır. Sessizlik konusu "konuşmanın 
tersi" düşüncesinin ötesinde değerlendirilmiş, yönetim ve psikoloji ile ilgili dergilerde sessizlik kavramına yer verilmiştir. Başlangıçta sessizlik, bağlılık göstergesi ya da onaylama anlamına gelen ses çıarmama olarak değerlendirilse de daha sonra örgüt performansını ve çalışanları olumsuz etkileyen bir davranış olarak kavramlaştırılmaya çalışılmıştır. Yönetim yazınında, örgütlerde sessizlik olgusu ile doğrudan ilişkili iki temel kavramsal çalışmadan söz edilebilir. Bu çalışmalardan ilki Morrison ve Milliken (2000) tarafından yapılmıştır. Morrison ve Milliken, örgütlerde sistematik olarak gelişen sessizlik sürecini ve bu sürecin sürekliliğini ve güçlenmesini sağlayan örgütsel koşulları açılamaktadır. İkinci önemli çalışma da Pinder ve Harlos (2001) tarafından yapılmıştır. Pinder ve Harlos algılanan adaletsizlik konusunda, çalışanların açıkça konuşma ya da konuşmamaya dair kararları üzerine odaklanmışlardır. Çalışan sessizliği kavramını geliştirmişler, çalışan sessizliğine neden olan ve sessizliği güçlendiren örgütsel koşulları açıklayan bir model önermişlerdir. Araştırmacılar, çalışan sessizliğini, "değişimi etkileyebilme ya da düzeltebilme yeteneğinde olduğu algılanan insanlara, örgütsel durumlarla ilgili konularda, kişinin davranışsal, bilişsel ve/ veya duygusal değerlendirmeleri hakkındaki samimi düşüncelerini esirgemesi" olarak tanımlamaktadırlar. Morrison ve Milliken (2000) ile Pinder ve Harlos (2001) tarafından yapılan sessizlik olgusuyla doğrudan ilgili iki temel kavramsal çalışmada ve daha sonraki çalışmalarda yer alan tanımlamalarda genellikle "bilgi ve fikrin kasten esirgenmesi" ve "örgütsel konu ve sorunlarla" sınırlı olması şeklinde iki ortak vurgunun olduğu görülmektedir. Van Dyne vd. tarafından 2003 yılında yapılan, örgütsel sessizliği ve sesliliği kendi içinde sınıflandırarak sessizliği çok boyutlu bir yapı olarak değerlendiren çalışma bu döneme öncülük etmiştir ve örgütsel sessizlik yazınında önemli bir yere sahiptir (Durak, 2012: 47; Çakıc1, 2010: 9-19; Çakıc1, 2008: 118). Van Dyne ve diğerleri (2003: 1362), çalışan davranışlarını aktif ya da pasif olma durumlarına göre bireysel düzeyde inceleyerek, sessizliği ve sesi belirleyen üç temel güdü (razı olma, kendini koruma, diğerlerini koruma), bunun sonucunda da üç tür sessizlik (kabullenici, korumacı, prososyal) ve buna paralel olarak üç ses (kabullenici, korumacı, prososyal) türünü tasvir etmişlerdir.

Brinsfield ve arkadaşları (2009: 18) mevcut dalga kapsamında örgütsel sessizlik, çalışan sessizliği gibi kavramları ele almışlar ve sessizlikle bağlantılı olduğunu düşündükleri işi bırakma, örgütsel öğrenme ve kavramları üzerinde bilgi paylaşımı gibi konular üzerinde durmuşlardır.

\section{Örgütsel Sessizlik Nedenleri}

Bu çalışmada örgütsel sessizliğin nedenleri, yönetsel ve örgütsel nedenler ile bireysel nedenler olmak üzere iki başlık altında incelenmiştir.

\section{Örgütsel Sessizliğin Yönetsel ve Örgütsel Nedenleri}

Örgütsel sessizliğin yönetsel ve örgütsel nedenleri, yöneticilerin olumsuz geribildirim korkusu, yöneticilerin örtük inançları, örgütsel yapılar, politikalar ve uygulamalar, toplu duyarlılık yoluyla paylaşılan algıların oluşturulması, algılama sürecinde bozulma, çalışanlar ve üst düzey yöneticiler arasındaki demografik farklılıkların doğrudan etkilerinden oluşmaktadır. 


\section{Yöneticilerin Olumsuz Geribildirim Korkusu}

Örgüt üyelerinin konuşabilmeleri için birtakım örgütsel şartların oluşması gerekir, bunlardan biri, çalışanların taleplerini yöneticilere ileten iletişim kanallarının açık olmasıdır. Yöneticiler, çalışanların görüşlerine karşı çıktıklarında veya reddettiklerinde, çalışanlarda konuşmanın riskli olduğu ya da çaba gerektirmeye değmeyeceği yönünde bir algı oluşur (Durak, 2012: 66). Örgütlerde bir sessizlik ortamı oluşturmayı kolaylaştıran önemli faktörlerden biri üst yöneticilerin, özellikle astlardan gelen olumsuz geri bildirim alma korkusudur. İnsanların sıklıkla, sahip oldukları bilgiler ya da kişisel hareketleri ile ilgili olumsuz geribildirimler almaları durumunda kendilerini tehdit altında hissettiklerini gösteren güçlü kanıtlar vardır. $\mathrm{Bu}$ nedenle, insanlar olumsuz geri bildirim almaktan kaçınmaya çalışırlar ve geri bildirimi aldıklarında ise mesajı görmezden gelmeye çalışabilirler, mesajın hatalı olduğunu düşünürler veya kaynağın inanılırlığına saldırabilirler (Morrison ve Milliken, 2000: 708).

Örgüt düzeni içerisindeki hiyerarşik yapıda her yöneticinin bir de üst yöneticisi veya değerlendiricisi bulunmaktadır. Çalışanlar tarafından yapılacak olan her geri dönüşü ara yönetici kendisi için risk olarak algılayabilir ve sessizlik iklimi oluşturabilir (Öztürk ve Cevher, 2016: 73). Birçok yönetici utanç, tehdit korkusu, hassasiyet veya yetersizlik duygularından uzaklaşmak için geri bildirim almaktan kaçınmaya güçlü bir biçimde ihtiyaç duymaktadır. Dolayısıyla, bu yöneticiler zayıflıkları karşısında sunulan önerileri veya mevcut faaliyet biçimleri hakkındaki soruları önleme eğiliminde olacaktır. Yöneticilerin özellikle astlardan gelen olumsuz geri bildirimleri önleme eğilimi gösterdiği yönünde kanıtlar vardır. Olumsuz geri bildirim, yukarıdan ziyade aşağıdan geldiğinde, daha az doğru ve haklı, kişinin gücünü ve güvenilirliğini daha fazla tehdit edici olarak görülmektedir (Morrison ve Milliken, 2000: 708). Yöneticiler, çalışanlardan aldıkları olumsuz geri bildirimden sonra, öz eleştiri yaparak kendilerini gözden geçirmek yerine karşısındaki kişileri eleştirmeyi ya da suçlamayı tercih edebilmektedir (Durak, 2012: 67).

Türkiye'de geribildirim uygulamalarının önünde ciddi bazı engeller bulunmaktadır. Kültürümüzde geri bildirim almak da vermek de oldukça zor bir durumdur. Ülkemizde, geribildirim sürecinde, mesajların doğru iletilmesi, geribildirim alan kişiye açıklama ve savunma hakkı verilmesi ve geribildirimi veren kişinin de onu dinlemeye hazır olması gibi temel kuralların uygulanmasını teşvik eden bir atmosfer bulunması olasılığı azdır. Olumsuz geri bildirimin, alan için de veren için de kültürden bağımsız olarak zor olduğu söylenebilir. Ancak kültürden kaynaklanan nedenlerle, olumsuz geri bildirim ile baş edilmesi çok daha zor bir sürece dönüşebilir. Olumsuz geribildirim alan ve veren kişiler, gelişecek olumsuz duygular ile karşı karşıya kalacaktır (Sümer, 2007: 376-378)

\section{Yöneticilerin Örtük İnançları}

Örgütsel sessizliğin temelinde yatan bir diğer önemli faktör, yöneticilerin çoğu zaman çalışanlar ve yönetim ile ilgili örtük inançlarıdır. Bu inançların ilki, çalışanların kendi çıkarlarını düşünen, tembel ve güvenilmez kişiler olduklarıdır. McGregor'un (1960) X Teorisine benzeyen bu inanç, bireylerin kendilerini ilgilendiren konularda ve bireysel araçlarını en üst düzeye çıkarmak için hareket ettiğini, örgüt yararına davranış göstermede sorumsuz ve tembel olduklarını, herhangi teşvik veya yaptırım olmaksızın örgütün menfaatlerini korumak için güvenilemeyeceklerini savunur. Diğer bir örtük inanç ise, örgütün yararına en iyi olanı yöneticilerin bileceği inancıdır. Bu inanç yöneticilerin çalışanları 
"ekonomik insan" olarak düşünmelerinden kaynaklanmaktadır. Çalışanlar bencil ve çalışmaktan kaçınıyorlarsa, muhtemelen örgüt için neyin en iyi olduğunu bilemeyeceklerdir. Son örtük inanç ise, örgüt içinde fikir birliği ve uzlaşma olmasının örgütün sağlıklı olduğunun bir göstergesi olduğudur. Örgütte sessizlik varsa her şey yolunda ve herkes memnundur düşüncesi hâkim olabilir (Morrison ve Milliken, 2000: 708-710; Durak, 2012: 68).

Düşük güç mesafesi eğilimi olan toplumların, güç eşitliği ile ilgili talepleri ve beklentileri fazladır, eşitsizliğin minimum düzeyde olması gerektiği yönünde yaygın bir inanç vardır. Buna karşın ülkemiz gibi yüksek güç mesafesi olan toplumlarda ise hiyerarşiyi kabul etme eğilimi daha fazladır, yöneticiler ile çalışanlar arasında bir fark olması gerektiği yönünde bir inanç vardır. Güç mesafesinin yüksek olduğu bir örgütte yöneticilerin en iyiyi bildiği düşünülür ve bu inanç örgütsel sessizliğe yol açan önemli bir faktördür (Durak, 2012: 69). Üst yönetimin kültürel değerleri de yöneticilerin çalışanlar hakkındaki inançlarını etkilemektedir.

$\mathrm{Bu}$ inanç ve yargılara sahip yöneticiler, astlardan gelen bilgilere ve görüşlere kapalı, açıkça konuşmayı desteklemeyen ve sorun bildirenlere olumsuz tepkiler veren bir yönetim anlayışı sergileyebilirler. Açıkça konuşanları ödüllendirmeyerek gizli veya açı şekilde cezalandıran üst yönetim; sessizlik iklimi, sağır kulak sendromu ve haksızlık kültürünü besleyen bir örgütsel ortam oluşmasına neden olabilir. Bu örtük inançlar, aynı zamanda sıkı kontrol mekanizmaları, merkezileşme, dikey hiyerarşik yapı, yukarı doğru iletişim mekanizmalarının eksikliği gibi uygulamalara kaynaklık edebilirler. Bu yapı ve uygulamalar, çalışanlar arasında, sorunlar hakkında konuşmanın anlamsız ve riskli olduğu algısının paylaşılmasına yol açabileceği gibi yöneticilere güven duyulmasını da engelleyebilir (Çakıcı, 2010: 29-30).

\section{Örgütsel Yapılar, Politikalar ve Uygulamalar}

Yöneticilerin inanç ve varsayımları, hem onların davranışlarını ve tercihlerini etkiler hem de çalışanları etkiler. Örneğin yöneticiler, çalışanların iş yapmaktan kaçındıklarını ve iyi bir iş yapmak için güvenilemeyecek olduklarını varsayarak kontrol mekanizmaları kurarlar. Yönetimin kendilerine güvenmediğini fark eden çalışanlar, yönetime karşı tavır alarak sistemlerde boşluklar bulmaya çalışır. Çalışanların bu tepkisi de yöneticilerin ilk inançlarını güçlendirmektedir. Çalışanların kendi çıkarlarını düşündükleri, yöneticilerin en iyiyi bildiği ve örgüt içinde anlaşmazlığın kötü olduğu yönündeki dile getirilmeyen hâkim düşünce, yönetimin yukarı doğru bilgi akışını zorlaştıran örgüt yapısı inşa etmesine neden olur. Bu eğilim, yöneticilerin herhangi bir tehdit edici bilgi veya geribildirimden kaçınma arzusuyla güçlenecektir. Bu inançların egemen olduğu örgütlerin iki ortak yapısal özelliği, karar alma mekanizmasının merkezileştirilmesi ve resmi geri bildirim mekanizmalarının olmamasıdır, çalışanların fırsatçı olduğu düşünülür ve yöneticilerin karar verme süreçlerine dâhil edilmezler, yöneticiler bu inançlarını çalışanların karşısına çıkarmak eğiliminde olurlar (Morrison ve Milliken,2000: 712-713).

Hisyerarşi kültürüne sahip örgütlerde, sessizlik davranışının görülme ihtimali yüksektir. Dikey örgüt yapılarında, üst yönetimin alt kademelerde bulunan çalışanlar ile etkileşimi, iletişimi ve onlara güveni düşük düzeyde olacaktır (Durak, 2012: 70). Katı bir yönetim tarzını benimseyen yöneticiler tercih ettikleri uygulamalar ve politikalar ile çalışanların sessizliği tercih etmelerine ve bir süre sonra örgütsel sessizliğin örgüt içinde sık karşılaşılan bir davranış haline gelmesine neden olabilir. 


\section{Toplu Duyarlılık Yoluyla Paylaşılan Algıların Oluşturulması}

Birçok örgütte, bilginin yukarı akışını engelleyen örgüt yapısı ya da problemleri dile getirmeyi engelleyen uygulamalar ile örgütsel sessizliğin yaygınlaştırılmasına tam olarak nasıl yol açtığını anlamak için, sessizlik ortamının gelişimini ve bu iklimin içine girdiği toplu duyarlılık oluşturma sürecini anlamak gerekir. Örgüt iklimi belli bir çalışma ortamının psikolojik açıdan önemli yönlerinin paylaşıldığı kalıcı algılamaları ifade eder. İklim, bireysel ihtiyaçlara veya motivasyon durumlarına göre güçlü bir davranış belirleyicisi olabilir. Sessizlik iklimi, paylaşılan "örgütteki sorunlar hakkında konuşmak için çaba sarf etmeye değmez" ve "görüş ve endişelerini dile getirmek tehlikelidir" inançları ile nitelendirilen bir ortamdır ve insanlar arasındaki etkileşimlerden oluşmaktadır. Sessizlik iklimi, çalışanların algılarını ve deneyimlerini paylaştığı, çalışma ortamının çeşitli yönleri hakkında ortak bir anlayışa sahip oldukları toplumsal etkileşimler yoluyla gerçekleşir. Bireyler, inançlarını ve algılarını, değerlendirme ihtiyacı ile başka çalışanlarınki ile karşılaştırırlar (Morrison ve Milliken, 2000: 714).

Çalışanlar, sosyal etkileşim ile algılarını ve deneyimlerini paylaşarak örgüt içinde ortak bir alg1 oluştururlar. Örneğin, yöneticlerin astların fikirlerini görmezden gelmeleri ya da muhalif astların terfi ettirilmemeleri gibi durumlarda, çalışanlar konuşmanın riskli ya da gereksiz olduğu yönünde bir görüşte birleşebilirler. Bunlara benzeyen yönetsel davranışların yaygın ve belirgin olmasına göre, örgütsel sessizleşme konusunda ortak niyet oluşturma da o kadar hızlı yaygınlaşır (Çakıcı, 2007: 156).

Örgütsel karar verme merkezileştirildiğinde ve yukarı doğru iletişim kısıtlandığında, yöneticilerin çalışan görüşlerini dikkate almaması ve çalışanların da konuşmanın riskli veya çabaya değer olmadığı görüşünde birleşmeleri muhtemeldir. Bu yapılar ve yönetsel davranışlar ne kadar yaygın olursa, konuşmanın hoş karşılanmadığ yönündeki paylaşılan algıları geliştirme olasılığı artar. Bununla birlikte, bu yapıların ve eylemlerin, sessizlik iklimine yol açma ihtimali, çalışanlara ortak algılamalar oluşturmak için uygun durumlar sağladığında daha fazla olacaktır. Kollektif duyu oluşturma süreci, bir yandan örgütsel yapılar ve yönetim uygulamaları ile iklim arasındaki ilişkiyi ılımlı hale getirmektedir. Dolayısıyla, bir örgüt içinde bir sessizlik ortamının nasıl geliştiğini anlamak için, bu süreci ve meydana gelme olasılığını artıran faktörleri anlamak gerekir. Ortak alg1 ve tutumların, bir sosyal birim üyelerinin birbirleriyle etkileşim ve iletişim kurma fırsatlarına sahip olması durumunda, gelişme ve güçlenmeleri muhtemeldir. Etkileşim ve iletişim ne kadar sık ve şiddetliyse "toplumsal bulaşma" (bir kişiden diğerine yönelik tutum ve algılamaların yayılması) ihtimali de o kadar fazladır (Morrison ve Milliken, 2000: 715).

Bireyler, kendilerini en rahat hissettikleri ve kendileriyle benzer olduklarını düşündükleri kişilerle etkileşime girmekte ve aynı kişileri de inançlarını ve algılarını doğrulamak için referans olarak kullanmayı tercih etmektedirler. Dolayısıyla, çalışanları sessizliğe iten örgütsel bir yapıda, çalışanlar arasında yüksek bir benzerlik derecesi olduğunda sessizlik iklimi ortaya çıkma ihtimali daha yüksek olacaktır. Bu ağda yer alan bir kişinin farklı kaynaklardan elde ettiği bilgiler neredeyse aynıdır. İnformal bağlar, örgütsel inanç ve tutumların iletildiği kritik kanallardır. Güçlü bağlar daha fazla etkileşim ve iletişimi sağlayacağı için toplu duyarlılık yoluyla paylaşılan algıların artması ve daha fazla çalışanın konuşmayı riskli olarak algılaması ihtimalini arttırır. Ayrıca yoğun sosyal bir ortamda ortaya çıkan bu güçlü bağlar toplu duyusallaştırmayı kolaylaştıracaktır ve toplu duyusal yapılanmanın gerçekleşmesini sağlayacaktır (Morrison ve Milliken, 2000: 716). 


\section{Algilama Sürecinde Bozulma}

Sessizlik ortamının ortaya çıkmasını etkileyebilecek toplu duyu oluşturma süreci, çalışanların gözlemlerini ve deneyimlerini paylaşarak topluca yorumlamaları nedeniyle önyargılı ve çoğunlukla yanlış algılamalara neden olan güçlü bir eğilime sahiptir. Çalışanlar, sınırlı ve çoğunlukla bozulmuş bilgilerle hareket ederler. Araştırmalara göre bireyler, kendi gerçeklerinden çok diğer insanların inandıklarına daha fazla güvenmektedir. Bir birey, kişisel deneyimleri ile örgütte ses çıkarmanın memnuniyetle karşılandığını bilse bile, diğer örgüt üyeleri örgütte bunun kabul edilemez olduğunu düşünürse, birey de bu görüşü benimseme eğilimi gösterecektir. Ayrıca, örgüt içindeki konular ve sorunlar ile ilgili olarak sessiz kalmayı seçen diğerleri, konuşmanın tabu olduğuna dair algılamayı güçlendirecektir ve toplu duyu oluşturma süreci, muhtemelen risk alma ve konuşma yetersizliği konusunda abartılı algılamalara neden olacaktır. Çalışanların, konuşmanın tehlikeli olduğuna dair ortak algı güçlenmesi ile sessizliği tercih etme ihtimalleri artacaktır (Morrison ve Milliken, 2000: 716717).

Yöneticiler tarafından görüşleri dikkate alınmayan çalışanlar, konuşmanın gereksiz olduğunu düşünmeye başlayabilir. Ayrıca görüşlerini açıkça ifade eden bir çalışanın örgüt içerisinde karşılaşacağı zorluklar, bazı çalışanlar tarafından yanlış bir şekilde anlaşılabilir ve yaşanan zorlukların konuşmanın bir sonucu olduğunun düşünülmesine neden olabilir. Alg1 sürecinde meydana gelen bu bozulmanın diğer örgüt üyelerine de yayılmasıyla, konuşmanın gereksiz olduğu algısı ya da olumsuz görüş bildirenlerin cezalandırılacağı yönünde doğru olmayan bir algı ortaya çıabilir ve örgütsel sessizliğe neden olabilir.

\section{Çalışanlar ve Üst Düzey Yöneticiler Arasındaki Demografik Farkhlıkların Doğrudan Etkileri}

Üst düzey yöneticiler ve alt düzey çalışanlar arasındaki demografik farklılıkların, yönetimin sessizliğe katkıda bulunan inançlarını arttırma ihtimali vardır. Aynı zamanda bu değişkenin, alt düzey çalışanların algılarını ve inançlarını etkileyerek bir sessizlik iklimine doğrudan katkıda bulunması da muhtemeldir. Çalışanların, kendilerine benzeyen insanları üst yönetimde görmediklerinde, örgütün kendilerine benzeyen insanların görüşlerini değerlendirmediği sonucuna varma ihtimali yüksektir. Görüşlerini dürüstçe dile getirmeleri durumunda, tepedeki kişilere daha çok benzeyen çalışanlara kıyasla, daha fazla risk taşıdıkları inancını oluşturabilirler (Morisson ve Milliken, 2000: 717). Yöneticiler ve astlar arasında demografik açıdan daha fazla farklılık olduğunda, sessizlik ikliminin ortaya çıma olasılığı daha yüksektir.

\section{Örgütsel Sessizliğin Bireysel Nedenleri}

Çalışanlar örgüte katkıda bulunmayı deneyebilir fakat kendine zarar gelebileceğini hissetmesi durumunda ya da olumsuz bir tepki ile karşılaşması durumunda katkıda bulunmak için çaba sarf etmeyi tekrarlamaz ve sessizlik davranışını tercih edebilir.

Sessiz kalma davranışı konulara ve bireylere göre farklılık göstermektedir. Bir kişinin sessiz kalma davranışı her zaman ve her ortamda farklılık gösterebilir, bu tip durumların sebebini tek bir etkene bağlamak mümkün değildir, geçmişte yaşanan olaylar ve bu olaylara verilen tepkiler sessizliğe yol açabilir, yaş, eğitim, cinsiyet, deneyim gibi özellikler sessizlik davranışını tercih etmede etkili olabilir. 
Yaş, bireyin sessiz kalma davranışını etkileyen önemli etkenlerden biridir. Gençlik dönemlerinde çalışanların işe uyum konusunda bazı zorluklarla karşılaşmaları sonucu iş değiştirme eğilimleri daha yüksek olabilir ve daha tepkisel davranabilirler. Yaş ilerledikçe çalışanların uyum düzeyi yükselir ve sorumluluk almaya istekli olurlar. Diğer bir sessizlik faktörü olan eğitim ise, kişileri toplumla olan ilişkilerinde güçlü kılan, bireyin birçok alanda ilerlemesini ve görüşlerini ifade etmesini sağlayan bir etkendir. Eğitim seviyesinin artması kişilerin bilgi ve görüşlerini ifade etmelerini kolaylaşatıracak ve sessizlik davranışını daha az tercih etmelerini sağlayabilecektir. Sessizlik üzerinde etkili olan, hem çalışma hayatındaki mesleki bilgilere hem de kişiler arası iletişime dayanan deneyim, bir öğrenme sürecidir ve kişilerin sessiz kalmasını etkileyebilmektedir. Olumsuzluklar karşısında alınan tepkiler ile kazanılan deneyim, kişilerin sessiz kalmayı tercih etmesine neden olabilmektedir. Sessizlik üzerinde etkili olan faktörlerden biri de cinsiyettir. Kadınlar toplum içinde deneyimlerini ve fikirlerini duyurmaları için teşvik edildiklerinde bile seslerini duyurmada zorluklarla karşılaşmakta, erkekler ise fikirlerini belirtmede daha başarılı olmaktadır (Özgen ve Sürgevil, 2009: 315-316). Örgütlerde kadın ve erkek çalışanlar arasında adil olmayan uygulamalara neden olabilen cinsiyet kalıp yargıları kişilerin davranışları ve beklentileri üzerinde, ücret farklılıklarından terfi kararlarına kadar birçok süreç üzerinde etkili olmaktadır. Bu durum kadın çalışanların aleyhine sonuçlar oluştururken erkek çalışanların kayırıldığı bir ortama neden olabilmektedir. Örgütte oluşan bu eşitsizlik birçok olumsuz sonuca neden olabilecek etkiye sahiptir (Uysal Irak, 2010: 192-193). Ataerkil toplum yapısı nedeniyle kadınlara yüklenen bazı rollerin varlığı, kadınların iş doyumları ve örgüte bağlılıklarını azaltarak sessiz kalmalarına neden olabilmektedir.

Sessizlik tercihini etkileyen diğer bir faktör, ortama uyum gösterme davranışı olan kendini uyarlamadır. Kendini uyarlama düzeyi yüksek kişiler, toplumda iyi bir izlenim birakmak amacıyla davranışlarını kasıtlı olarak değiştirebilen kişilerdir. Kendini uyarlama düzeyi düşük kişiler ise duygularını, düşüncelerini, değer yargılarını yansıtabilen kişilerdir ve açıkça konuşma davranışını tercih ederler (Çakıcı, 2010: 24).

Mobbing de örgütsel sessizliğe neden olan faktörlerdendir. Mobbing mağduru kişilerin gösterebileceği tepkilerin başında, kendini örgütten soyutlayarak, olumlu veya olumsuz hiçbir konuda fikir ve düşüncelerini dile getirmeme davranışı yer alacaktır (Gül ve Özcan, 2011: 131).

\section{Örgütsel Sessizlik Türleri}

Sessizlik, kişinin aktif olarak iletişim kurmaması olarak görülebilse de, sessizlik yalnızca sesten yoksun olmak değildir, çalışanların fikirleri, bilgileri ve görüşleri olmasına rağmen, bunları ifade etmemeyi seçme durumudur. Farklı sessizlik biçimleri farklı çalışan güdüleri tarafından yönlendirilmektedir (Van Dyne vd., 2003: 1366). Örgütsel sessizlik, başkalarının görüşlerine uyma, kendini koruma başkalarını düşünerek hareket etme sebebiyle farklı şekillerde ortaya çıkabilmektedir (Taşkıran, 2011: 76).

Sessizlik kavramı ile ilgili yapılan araştırmalar sonucunda, çeşitli araştırmacılar tarafından birkaç sessizlik sınıflandırması yapılmıştır.

Bruneau (1973) yapmış olduğu sessizlik sınıflandırmasını, pragmatik sessizliğe dayandırmıştır. Brunea (1973)'a göre pragmatik sessizlik, bireylerin zaman zaman kendi fikirlerini söylemeyi tehlikeli bularak, kasıtlı olarak konuşmaktan kaçınmaları ve genellikle de 
stratejik bir amaç için konuşmamayı seçmeleridir. Bruneau, pozitif ya da muhalefetsiz iletişim kurabilen pragmatik sessizliğin üç biçimini tanımlamıştır, bunlar psiko-dilbilimsel, etkileşimli ve sosyokültürel sessizliklerdir. Psiko-dilbilimsel sessizlik, konuşma esnasında istenmeden yapılan, kasıtlı olmayan duraksamaları içeren psikolojik temelli sessizlik türüdür. Etkileşimli sessizlik, karşılıklı görüş alış-verişleri sırasında genellikle stratejik ve kasıtlı olarak yapılan sessizliktir. Sosyo-kültürel sessizlik, çoğunlukla oldukça resmileştirilmiş grup veya örgüt içerisindeki duraklamaları ifade eden sessizlik türüdür (Pinder ve Harlos, 2001: 338 - 340).

Sessizlik konusunda önemli çalışmaları bulunan Pinder ve Harlos (2001), sessizliği "pasif" ile "razı olma" şeklinde sınıflandırmışlardır. Pinder ve Harlos (2001: 348-349), pasif sessizliği çalışanların kasıtlı olarak ses çıkarmamaları şeklinde tanımlamıştır. İşyerindeki adaletsizlik bağlamında bu sessizlik şekli, kişinin kendinin ya da başkalarının desteği veya kışkırtması ile değiştirilebilir olan rahatsız edici, bilinçli bir durumu ifade etmektedir. Pasiflik durumu; çalışanların, kendilerine dayatılan koşulları kabul etmemeleri ve bu mevcut durumu değiştirme konusunda çeşitli alternatiflerin var olduğunu bilmelerine rağmen, bunları dile getirmeleri halinde kendilerine olumsuz bir geribildirim döneceği endişesi ve korkusuyla sükûnetlerini koruyarak gönüllü bir biçimde pasifliği tercih etmeleri anlamına da gelmektedir. Buna rağmen, pasifliği tercih eden çalışanlar sessizliği besleyen ve üreten koşulları değiştirmek için sessizliklerini bozmaya hazırdırlar.

Pinder ve Harlos, ileri sürdükleri diğer sessizlik şekli olan razı olma kavramını ise, pasifliğin aksine, boyun eğmek hatta göz yummak şeklinde tanımlamıştır. Dolayısıyla razı olma, mevcut durumu garanti altına alan ve alternatif durumların var olduğunun sinırlı olarak farkında olunduğu, örgütsel koşulların kabulünün çalışanlar tarafından daha derinden hissedilmesidir. Razı olma sessizliği, pasif sessizlikten daha derin bir durumu ifade etmektedir, pasif sessizliğe göre daha fazla destek veya daha fazla kışkırtma olması gerekmektedir. Razı olan örgüt üyeleri, pasif üyelere göre sessizleştiklerinin daha az farkındadırlar. Pasif sessizliğe benzer şekilde, razı olma sessizliği de rahatsız edicidir ve motivasyon kapasitesi ise daha zayıftır. Ses çıkarma veya şikâyet etme konularında örgüt üyelerini harekete geçirmek için pasif sessizliğe oranla razı olma sessizliğinde daha fazla motive edici faktöre ihtiyaç duyulmaktadır. Pinder ve Harlos, her iki sessizlik boyutları arasındaki farkı gönüllülük, bilinç, kabul, stres düzeyi, alternatiflerin farkında olma, ses çıarma eğilimi, işten ayrılma eğilimi ve baskın duygular açısından açıklama yoluna gitmişlerdir (Pinder ve Harlos, 2001: 352). Pinder ve Harlos (2001)'un sessizlik boyutları pasif ve razı olma sessizliğinin alt boyutlara göre farklılıkları Tablo 1'de yer almaktadır. 
Tablo 1. Pinder ve Harlos'a Göre Pasif Sessizlik ve Razı Olma Sessizliğinin Boyutları

\begin{tabular}{lll}
\hline Boyutlar & $\begin{array}{l}\text { Pasif Sessizlik } \\
\text { (Quiescence Silence) }\end{array}$ & $\begin{array}{l}\text { Razı Olma Sessizliği } \\
\text { (Kabullenici Sessizlik) } \\
\text { (Acquiescence Silence) }\end{array}$ \\
\hline Gönüllülük & Nispeten gönüllü & $\begin{array}{l}\text { Nispeten gönülsüz } \\
\text { Bilinç }\end{array}$ \\
Kabul & Dilinçli & Daha az bilinçli \\
Stres Düz̧ük & Orta ile yüksek arası \\
Alternatiflerin Farkında Olma & Nispeten yüksek & Düşükten ortaya doğru \\
Ses Çıkarma Eğilimi & Nispeten yüksek & Nispeten düşük \\
İşten Ayrılma Eğilimi & Nispeten yüksek & Nispeten düşük \\
Baskın Duygular & $\begin{array}{l}\text { Korku, öfke, umutsuzluk, sinizm, } \\
\text { depresyon }\end{array}$ & Nispeten düşük \\
\hline
\end{tabular}

(Kaynak: Pinder ve Harlos, 2001: 350)

Van Dyne ve diğerleri (2003) ise Pinder ve Harlos (2001)'un sessizlik sınıflandırmasını temel almıs, ancak yönetim, etik ve iletişim yazınlarını derinlemesine inceleyerek, Pinder ve Harlos (2001)'un geliştirdiği iki sessizlik türüne yeni bir tür daha ekleyerek, kabullenici, savunma (korunma) amaçlı ve koruma amaçlı (örgüt yararına/ prososyal) sessizlik olmak üzere üç farklı sessizlik türü tanımlamışlardır (Van Dyne vd., 2003:1364).

\section{Kabullenici Sessizlik}

Kabullenici sessizlik (acquiescent silence), çalışanların mevcut duruma razı olup, görüş, bilgi ve düşüncelerini kendilerine saklayarak, pasif bir davranış sergilemeleri olarak ifade edilebilir (Van Dyne vd., 2003: 1366). Başka bir ifadeyle çalışanların işsiz kalmama veya terfi edebilmek gibi amaçlar doğrultusunda, olaylar karşında sessiz kalmaları ve düşüncelerini dile getirmekten kaçınmalarıdır (Öztürk ve Cevher, 2016: 74).

Kabullenici sessizliğin bir parçası olan itaat kavramı, içinde bulunulan şartların sorgulanmadan kabul edilmesi ve mevcut alternatiflerin sınırlılı̆̆ını ifade etmektedir. İtaatkâr çalışanlar içinde bulundukları şartları sorgulamadan kabul eder (Pinder ve Harlos, 2001: 349). Kabullenici sessizlikte, çalışanların bilgi sahibi olmasına rağmen iletişim kurmaktan kaçınma davranışı ön plana çıkmaktadır (Özgen ve Süregevil, 2009: 311).

Koşulları olduğu gibi kabul etmek çalışana güven verir, dolayısıyla çalışanlar söz konusu koşulları değiştirmeye ve sorunlar için çözüm aramaya çalışmaz, kendilerine sunulan seçenekleri de kabul etmezler (Pinder ve Harlos, 2001: 349). Örneğin, bir çalışan, konuşmasının anlamsız ve fark yaratma imkânına sahip olmadı̆̆ı inancı ile kendi kendini, fikirlerini değiştirmek için zorlayabilir. Alternatif olarak, bir çalışan fark yaratamayacağı düşüncesinden dolayı görüsslerini ve bilgisini kendine de saklayabilir. Her iki durumda da sessizlik itaat temeline dayanmaktadır. Kabullenici sessizlik davranışı sergileyen çalışanların fikirleri veya 
önerileri ile örgüte proaktif bir biçimde katkıda bulunma olasılıkları düşüktür, kasıtlı olarak pasif davranış sergilerler, itaat duygusuna ve anlamlı değişikliklerin örgütün yeteneklerinin ötesinde olduğuna dair inanca sahiptirler (Van Dyne vd., 2003: 1366).

$\mathrm{Bu}$ sessizlik türünde, çalışanlar mevcut durumu kabullenirler ve durumu değiştirme girişiminde ya da açıkça konuşma çabası içinde olmazlar, kasıtlı olarak pasif ve ilgisiz davranışlar sergilerler. İlgisiz davranış boyun eğme temeline dayanabileceği gibi, konuşmanın yararının olmayacağı inancına da dayanabilir. Kabullenici sessizlik "Böyle gelmiş böyle gider.", "Bana dokunmayan yılan bin yıl yaşasın." gibi sözlerle ülkemizde kendini göstermektedir. Öğrenilmiş çaresizlik ile kabullenici sessizlik arasında arasında güçlü bir ilişki vardır. Önceki deneyimlerine dayanarak, ne yaparsa yapsın çevresini kontrol edemediğini gören öğrenilmiş çaresizlik içindeki insanlar, kabullenme ve sessizleşme davranışlarına eğimli olurlar. Bu kişiler örgütle ilgili sorunlara ve konulara karşı ilgilerini kaybederler. Kabullenici sessizlikte örgütsel konu ve sorunlara karşı ilgisizlik ya da düşük düzeyde ilgi söz konusu olup, durumu değiştirme çabası yoktur, sadece yapmak zorunda oldukları işleri yaparak zaman doldurma gayesi vardır (Çakıcı, 2010: 33).

Baskıcı ve otoriter bir ortamda yetişen kişilerin, örgüt içinde kabullenici sessizliği tercih etme ihtimalleri daha yüksektir. Ĕger bir örgütte, yöneticiler yetkilerin çok önemli bir kısmını kendilerinde toplamışsa, böyle bir örgütte çalışanların çoğunluğunun kabullenici sessizliği tercih etme ihtimalleri yüksektir. Ancak günümüzde bu davranış bir meziyet olmaktan çıkmış ve sakınca haline gelmiştir çünkü günümüzde kendisine verilen görevleri sorgulamaksızın yerine getiren bireyler örgüt içinde önemini kaybetmiş, düşünen, sorgulayan, farklı öneriler sunabilen bireyler önem kazanmaya başlamıştır (Durak, 2012: 53-54).

\section{Savunma (Korunma) Amaçlı Sessizlik}

Savunma amaçlı sessizlik (defensive silence), kendini dış tehlikelerden korumak amacıyla, fikir, bilgi ve görüşlerin güvence hissi ile kasıtlı olarak saklanmasıdır. Kabullenici sessizliğin aksine, kendini savunma güdüsü ile ortaya çıkan savunma amaçlı sessizlik; endişe ve korku temeline dayanan, kendini dış tehditlerden korumak için tasarlanmış kasıtlı ve proaktif davranıştır. Bu sessizlik türünde, çalışanlar alternatiflerin farkındadırlar ve bu davranışı bilinçli olarak göstermektedirler. Fikirlerin saklanması bilinçli bir takip kararına dayanmaktadır ve belli bir zaman diliminde en iyi kişisel strateji olarak düşünülmektedir (Van Dyne vd., 2003: 1367). Bilinçli bir risk değerlendirmesine dayandığı ve dışsal tehditlerden kendini koruma niyeti taşıdığı için daha proaktiftir (Çakıcı, 2010: 33).

Pinder ve Harlos (2001) pasif sessizliği (quiescence silence), açıkça konuşmanın sonuçlarından korkulması nedeniyle kasıtlı olarak sessiz kalma olarak açılamaktadır. Birey mevcut durumu değiştirmeye yönelik alternatif fikirlere sahip olmasına rağmen, kendini koruma adına onları dile getirmede isteksizdir. Morrison ve Milliken tarafından vurgulanan korku faktörü bu noktada önem kazanmaktadır. Yöneticilerden negatif geri bildirim alma korkusu, yöneticilerin çalışanların doğuştan tembel olduğu konusundaki inançları vb. çalışanların bu tür sessizlik davranışını göstermelerine neden olmaktadır (Taşkıran 2011: 79). Van Dyne ve diğerleri (2003), pasif davranışı ayrı bir sessizlik türü olarak değil de savunma amaçlı sessizlik içinde ele almışlardır. Pasif davranış, kabullenmeye göre geçici bir sessizlik hali olabilir ve kişi açıkça konuşmayı tercih edebilir, kişi haksızlığın farkındadır ve durumu düzeltebilecek insanlara sessizliğini bozmak için fırsat kollamakta olabilir. Örneğin iş yerinde kendisine 
tacizde bulunulmuş bir kadın çalışan, durumu değiştirebileceğine inandığı kişiye ulaşana kadar ya da kamu desteği göreceği ana kadar sessizliğini sürdürerek, haksızlığı sineye çekmiş olabilir (Çakıcı, 2010: 33-34).

Çalışanlar, korkuya dayalı olarak sorumlu tutulma korkusuyla, sorunlar hakkındaki bilgileri saklı tutmayı ya da kendini korumak için gerçekleri görmezden gelmeyi ve kendini korumak için kişisel hataları gizlemeyi tercih edebilirler, fikirlerini ve düşüncelerini dile getirmeleri durumunda fayda yerine zarar görebileceklerini düşünerek, güvenlik ihtiyacını ön plana çıkarabilirler. MUM (sessizlik) etkisi, savunma amaçlı sessizliğin örneklerindendir. MUM etkisi, insanların kişisel olarak rahatsız olmaktan, savunmacı yanıtlar almaktan veya olumsuz kişisel sonuçlardan kaçınmak için üstlerine kötü haberleri iletmekten kaçınmalarıdır (Van Dyne vd., 2003: 1367).

\section{Koruma Amaçlı (Örgüt Yararına/ Prososyal) Sessizlik}

Van Dyne vd. (2003: 1368) tarafından literatüre eklenen koruma amaçlı sessizlik (prosocial silence), işbirliği ile fedakârlık temelinde, örgüte veya örgüt içindeki diğer kişilere faydalı olmak amacıyla, işle ilgili bilgi, fikir ve görüşlerin saklı tutulmasıdır.

Koruma amaçlı sessizlik; çalışanın örgütü koruma güdüsüyle ya da diğer çalışanları koruma güdüsüyle hareket etmesi sonucu iki şekilde ortaya çıkmaktadır (Brinsfield, 2009: 146). Koruma amaçlı sessizlik başkalarına odaklanan kasıtlı, proaktif ve örgüt tarafından zorunlu tutulmayan, isteğe bağlı bir davranıştır. Savunma sessizliğine benzer şekilde, koruma amaçlı sessizlik; farkındalık ve alternatiflerin göz önünde bulundurulması ve fikir, bilgi ve görüşlerin bırakılmasına yönelik bilinçli karar üzerine kuruludur. Savunma sessizliğinin aksine, koruma amaçlı sessizlikte, açıkça konuşmaktan kaynaklanabilecek olumsuz kişisel sonuçlardan korkulmasından ziyade, başkaları için endişelenildiği ve diğer insanların yararı düşünüldüğü için sessizlik davranışı tercih edilmektedir (Van Dyne vd., 2003: 1368). Çalışanların koruma amaçlı sessizliği tercih etmesindeki amaç; örgüt, çalışma arkadaşları ve çevrelerinin iyiliği ve geleceği gibi konularda sessizliklerini koruyarak, düşüncelerini örgütün devamlılığını sağlaması için dile getirmemesidir (Öztürk ve Cevher, 2016: 74). Bu sessizlik türünde, çalışanlar "kol kırılır yen içinde kalır" düşüncesi ile hareket etmektedir.

Türk çalışanların kendilerini ait hissettikleri örgütlerin varlığını ve uyumunu devam ettirme kaygıları bulunmaktadır. Türk çalışanlar için, örgütten ayrılma kararı sadece bireysel bir getiri- götürü hesabı olmayıp, örgüt içerisinde gelişen ilişkileri bozmamak, örgüt için kendinden fedakârlık etmek gibi normları kapsamakta ve örgütsel bağlılıklarını etkilemektedir (Wasti, 2000: 205). Koruma amaçlı sessizliği tercih eden birey, örgüt içindeki dayanışmayı, birlik ve beraberliği bozmamak adına muhalif görüşlerini açılamaktan kaçınabilir, arkadaşını korumak adına işteki yetersizliği konusunda sessiz kalabilir ya da örgüt aleyhine kullanılabilecek özel bir bilgiyi örgütü korumak amacıyla dile getirmeyebilir (Çakıcı, 2010: 34). Bireyci batı toplumlarına kıyasla ülkemiz gibi toplulukçu değerleri yüksek toplumlarda, koruma amaçlı sessizliğin daha yaygın olduğu söylenebilir (Durak, 2012: 57).

Yöneticilerin, çalışanların sessiz kalma davranışlarının altında yatan güdüleri anlamaları kolay bir süreç değildir. Çünkü sessizlik, kasıtlı olarak bilgiyi ifade etmemeye dayanır ve bu yüzden konuşmaya göre daha karmaşık ve belirsiz bir durumdur. Konuşmaya göre daha örtüktür ve çalışanların hangi güdülerle sessiz kaldıklarını tespit etmek daha güçtür. Yöneticilerin, sessizliğin nedenlerini yanlış nitelendirmeleri de mümkündür. Bununla birlikte 
yöneticilerin, sessizliğin nedenlerini anlamaya çalışmak ve örgütsel iletişimi etkin hale getirmek gibi sorumluluğu da vardır. Aksi takdirde sessizlik davranışı kollektif bir hale gelir ve örgütün her yanını kaplarsa örgüte zarar verebilecek durumlar ortaya çıkabilir (Van Dyne vd., 2003: 1368; Çakıcı, 2010: 34). Zor bir süreç olmasına rağmen yöneticilerin, çalışanları konuşmaya teşvik edebilmek ve yenilikçi fikirleri üretim sürecine katabilmek için çalışanların sessizlik nedenlerini doğru tespit ederek yorumlamaları gerekmektedir (Durak, 2012: 58).

\section{Örgütsel Sessizliğin Etkileri}

Örgütlerin varlıklarını devam ettirebilmeleri için, çevredeki değişimlere uyum sağlayabilen, sahip oldukları bilgileri korkusuzca paylaşan, fikirlerini savunabilen çalışanlara ihtiyacı vardır. Bu özellikleri taşımayan çalışanlara sahip ya da sessziz kalmamaları yönünde çalışanlarını desteklemeyen örgütlerin, örgütsel bozulma ve değişime direnç gibi olumsuz sonuçların yanı sıra karşılaşabilecekleri bazı sorunlar şu şekilde sıralanabilir (Özgen ve Sürgevil, 2009: 321):

a. Örgüt içindeki iletişimsizlik nedeniyle çalışanların birbirinden uzaklaşması,

b. Bireysel sessizleşmeleri benimseyen çalışanların sosyal ortamdan çekilerek kendilerini örgütten soyutlamaları,

c. Sorunların dile getirilmemesinden kaynaklanan sessizliğin, örgütte yaygın bir kültür haline gelme tehlikesi,

d. Çalışanların örgüte bağlılıklarının, iş tatmininin ve verimliliklerinin azalması,

e. Çalışanların güvenlerini, motivasyonlarını azaltarak, stres, duyarsızlaşma ve işe yabancılaşma düzeyini arttırması,

f. Değişime uyum sağlayamama riski.

Çalışanların, bilgiyi paylaşma, konuşma ve geri bildirim sunma konusundaki isteksizliği, moral, motivasyon ve güveni olumsuz olarak etkileme potansiyeline sahiptir. Ayrıca, bilgi ve düşünceleri saklamak, örgütsel karar verme, hata düzeltme, geliştirme ve yenilik süreçlerini de zayıflatabilir (Vakola ve Bouradas, 2005: 443). Çalışanın sessizliği tercih etmelerinin olumsuz etkileri doğrudan ve dolaylı biçimde olabilir. Örgütsel sessizlik, kritik bilgilere yönetsel erişimi azaltarak işi doğrudan etkiler. Örneğin, süreklilik arz eden iyileştirme, mevcut çalışma süreçlerinde zayıf noktalar hakkında ipucu sağlayabilecek operasyonel problemlerin belirlenmesini gerektirir. Çalışanların sessizliği tercih etmesi, iyileştirme süreçlerinde sorunların ortaya çıkmasına neden olur ve örgütlerde yeniliği azaltır. Örgütsel sessizliğin dolaylı sonuçları da vardır, örneğin yolsuzluklara, kazalara neden olabilir, kasıtlı olarak iletişim kurmayan çalışanların stres ve psikolojik sorunlarını arttırabilir (Tangirala ve Ramanujam, 2008: 37-38).

Örgütsel Sessizliğin etkileri, karar alma ve değişim süreçleri üzerine etkileri ile çalışanların algı, tutum ve davranışları üzerine etkileri olmak üzere iki başlık altında toplanmıştır.

\section{Örgütsel Sessizliğin Karar Alma ve Değişim Süreçleri Üzerine Etkileri}

Örgütsel sessizliğin, örgütsel karar verme ve değişim sürecinde önemli bir etkisi vardır. Örgüt kararları ile ilgili araştırmalar, örgüt üyelerinin karar verme sürecine dahil edilmesinin karar 
kalitesini arttırdığını ve örgüt performansı üzerinde olumlu bir etkisi olduğunu göstermiştir. Ayrıca, yeniliklerin kabul edilebilmesi ve uygulanabilmesi için, çalışanların yeni fikirlerini korkusuzca dile getirebileceği bir örgüt ortamına ihtiyacı vardır. Örgütsel sessizlik karar alıcılar için bilgi akışlarını kısıtlayarak, örgütsel karar alma ve değişim süreçlerinin etkinliğini tehlikeye atacaktır. Diğer taraftan, çalışanlardan sınırsız bilgi girdisi sağlamaya çalışmak da arzu edilen bir durum değildir, çok fazla girdi, karar verme süreçlerine aşırı yüklendiğinde, zamanında ve etkili bir karar vermeyi engelleyebilir, karar alma ve değişim girişimlerinin kalitesini düşürebilir (Morrison ve Milliken, 2000: 719). Örgütsel sessizliğin örgütlere ve çalışanlara etkileri doğrudan ya da dolaylı olabilmektedir. Örgütsel sessizlik, yöneticilerin önemli bilgilere erişimini azalttığ 1 için işleri doğrudan, çalışanların mutluluğunu etkilediğinde ise işleri dolaylı olarak etkilemektedir. Sessizlik iklimi örgütlerde hataları fark etmeyi ve bunun sonucunda da örgütsel etkililiği olumsuz olarak etkilemektedir (Durak, 2012: 85).

Örgütsel sessizlik olumsuz geribildirimleri ve dolayısıyla bir örgütün hataları algılama ve düzeltme becerisini engellemektir. Olumsuzluklar düzeltilmediğinde, hatalar devam etme eğilimi göstererek yoğunlaşabilir, çünkü düzeltici önlemler gerektiğinde alınamaz. Daha da kötüsü, üst düzey yöneticiler önemli bilgilerden yoksun olduklarını kabul edemeyebilir ve sessizliği başarı olarak yorumlayabilir. Yöneticiler doğrudan çalışanlardan geribildirim istiyor olsa bile, çalışanlar olumsuz bilgileri filtrelemek için çaba sarf edebilirler. Sonuç olarak, yönetimin aldığ 1 geribildirim, çalışanların doğru ya da güvenilir tepkileri yerine, yöneticilerin düşündüklerini ve duymak istediklerini yansıtabilir (Morrison ve Milliken, 2000: 719).

Hataları fark ederek sorunları zamanında çözebilmek örgütsel değişim için hayati önem taşımaktadır. Bu nedenle çalışanların karar alma ve değişim süreçlerinde fikirlerini ve görüşlerini açıkça ifade edebilecekleri, sahip oldukları bilgileri paylaşmaktan korkmayacakları bir örgüt kültürü oluşturulması ve örgütsel sessizliğin önüne geçilmesi gerekmektedir.

\section{Örgütsel Sessizliğin Çalışanların Algı, Tutum ve Davranışları Üzerine Etkileri}

Örgütsel sessizliğin neden olduğu olumsuz sonuçlardan en önemlileri çalışanların örgüte olan bağlılıklarını azalması ve iş tatminsizliğinin ortaya çıkmasıdır. Örgütsel bağlılığı azalan ve yaptığı işten tatmin olmayan çalışanlar işten ayrılma düşüncesine kapılabilir, bu nedenle örgütler sürekli artan rekabet ortamında insan kaynaklarını doğru yönetmek için örgütsel sessizliğin önüne geçmelidir (Tayfun vd., 2016: 36).

Çalışanların, örgütsel sessizliği tercih etmeleri stres seviyelerini arttırarak psikolojik sorunlar yaşamalarına da sebep olabilir. Sorunlarla ilgili konuşamama ve açıkça fikirlerini dile getirememenin neden olduğu his; motivasyon, iş tatmini ve örgütsel bağlllıkta azalmaya neden olacak ve bu azalma ise zamanla çalışanların örgütle daha az ilgilenmelerine yol açabilecektir (Tangirala ve Ramanujam, 2008; Akt.: Zerenler, 2011: 161).

Örgütsel sessizliğin çalışanlar üzerinde; kendilerini değersiz görmeleri, kontrol edildiklerinde kendilerinde eksiklik algılamaları ve bilişsel uyumsuzluk göstermeleri gibi yıkıcı etkileri vardır ve bu etkiler örgütsel etkinliği zayıflatabilecek çeşitli ikinci derece sonuçlara yol açabilmektedir (Morrison ve Milliken, 2000: 720). Bu nedenle çalışanların kendilerini değersiz hissetmeleri, çevrelerini kontrol etme eksikliği algıları ve bilişsel uyumsuzluk yaşamalarını kısaca açıklamak faydalı olabilir. 


\section{Çalışanlarnn Kendilerini Değersiz Hissetmeleri}

Çalışanlar görüşlerini açıç̧a ifade edemediklerinde değersiz oldukları hissine kapılabilirler. Örgütün kendilerine değer vermediğini hissettiklerinde ise, örgüte duydukları güven ve örgüte verdikleri değer azalabilecektir (Morrison ve Milliken, 2000: 720). Örgütsel bağlllık ve güvenin azalması ise çalışanlarda daha düşük tatmine ve motivasyona yol açarak, psikolojik çekilme ya da örgütten ayrılmaya neden olacaktır (Durak, 2012: 76). Örgütsel sessizliğin neden olabileceği olumsuz sonuçları yaşamamak için yöneticilerin gerekli önlemleri alması ve öncelikle örgüt üyelerinin kendilerini değerli hissedecekleri bir örgüt kültürü oluşturmaları gerekmektedir.

\section{Çalışanların Çevrelerini Kontrol Etme Eksikliği Algıları}

Farklı bakış açllarına sahip ya da toplumsal duyarlılığı yüksek kişiler, seslerini çıkarmalarına rağmen sonuç alamadıklarını gördüklerinde, bir süre sonra sessizliği tercih edebilirler ve bu insanların çevrelerinde ne olup bittiğini kontrol etme ihtiyacı, umursamaz ve duyarsız kişilere göre daha fazladır (Çakıcı, 2010: 35).

Çalışanlar kendilerini etkileyen yakın çevre üzerinde güçlü bir kontrol isteğine sahip olmalarına rağmen, bazı durumlarda çevrelerini ve işlerini kontrol etme konusunda eksik kalabilirler. Çalışanlar fikir ve düşüncelerini açıklayarak çevreleri üzerinde kontrol duygusu elde ederler. Kendilerine konuşma imkânı tanınmadığı zaman ise, çalışanların kontrol ihtiyaçları karşılanmamış olur ve bu durumda kendilerini, yaptıkları işler ve çevrelerini etkileme konusunda güçsüz hissederler. Çalışanların kontrol eksikliği hissetmeleri ise motivasyonun azalması, tatminsizlik, strese bağlı rahatsızlıklar ve psikolojik geri çekilme gibi zararlı etkilere neden olmaktadır, stres ve psikolojik geri çekilme gibi davranışlar ise öğrenilmiş acizliği yansıtabilmektedir. Çalışanlar konuşma ya da diğer olumlu araçlarla kontrolü sağlayamadıklarını düşündüklerinde, örgüt için zararlı olan bir takım yollarla kontrolü sağlamaya çalışacaklardır. Çalışanların bilgiyi diğerlerinden esirgemesi ve konuşmaması stresin artmasına yol açabilmektedir ancak konuşmama, bazı durumlarda ve bazı şartlar altında akıllıca ve stratejik en iyi karar olabilmektedir (Brinsfield vd., 2009: 27; Akt.: Durak, 2012: 77).

\section{Çalışanların Bilişsel Uyumsuzluk Yaşamalan}

Örgütsel sessizliğin çalışanla üzerindeki üçüncü olumsuz etkisi, yapmayı düşündükleri ile yaptıklarının farklı olmasından dolayı bilişsel uyumsuzluk yaşamaları, oldukları gibi görünememelerinden ya da göründükleri gibi olamamalarından rahatsızlık duymalarıdır. Yanlış uygulamalara sessiz kalmak zorunda kalan kişi kendi inançları ile çelişerek, bu durumun verdiği iç sıkıntıyı sürekli olarak hissedecektir. Kişi inançları ile davranışları arasında çelişki yaşıyorsa, bilişsel uyuşmazlık yaşar ve örgütsel sessizlik bilişsel uyuşmazlığ arttırabilir, bu durumda kişiler, inançlarını veya davranışlarını değiştirerek uyumlu olmaya çalışırlar. Ancak inançlarını ve davranışlarını kolay değiştiremeyen çalışanların endişe ve stresleri giderek artar ve kendilerini iş yerine uyum sağlayamayan çaresizlik içinde bulurlar (Çakıcı, 2010: 35; Durak, 2012: 77). 


\section{Örgütsel Sessizliğe Karşı Alınabilecek Önlemler}

Sessizlik sorununun çözümünde yöneticiler baskın rol oynamaktadır, bu nedenle sessizliğin sürmesine neden olan koşulları kırmak ve örgüt içinde güveni oluşturmak yöneticilerin sorumluluğundadır. Yöneticiler kendi örtük inançlarını değiştirerek sessizlik ile mücadele etmeye başlamalıdır. Yöneticiler, endişelerini ya da sorunları dile getiren çalışanları içtenlikle dinleyerek, destekleyici bir tavır sergileyebilir ve çalışanların kendilerini güvende hissedebilecekleri bir iş ortamı oluşturabilirler (Çakıcı, 2007: 160).

Örgütsel sessizliğin çalışanlar üzerinde stres, düşük motivasyon, düşük bağlllık ve güven, sabotaj yapma eğiliminin yanı sıra, tatminsizlik, işten ayrılmaların yoğunluğu ve dolayısıyla personel devir hızının yüksek olması gibi sonuçları görülmektedir (Morrison ve Milliken, 2000: 720). Bu sonuçların yol açabileceği olumsuzlukları önlemek amacıyla, örgütsel sessizlikle mücadele etmek örgütler açısından önemli bir hale gelmektedir.

Örgütsel sessizliğin nedenlerinin ve sonuçlarının bilinmesi, örgütsel sessizlikle mücadelede bir yol haritası sunmaktadır. Bu doğrultuda örgütsel sessizlik ile ilgili alınabilecek önlemler şu şekildedir (Harlos, 2001: 330; Akt.: Özgen ve Sürgevil, 2009: 322):

a. Örgütte çalışanların bilgilerini ve becerilerini geliştirmeye yönelik eğitimler düzenlenmesi,

b. Soru-cevap programlari,

c. Çalışanlara danışmanlık hizmeti sunulması,

d. Öneri sistemlerinin geliştirilmesi,

e. İş ile ilgili anket uygulamaları ve anket sonuçlarının geri bildirimi,

f. Önerilere ilişkin teşvik ve ödül programlarının uygulanması,

g. Önerilerin kabul edilerek uygulanması ve bir güven ortamı oluşturulması,

h. Personel güçlendirme,

i. İletişim kanallarının açık olması.

Örgütlerin çalışanlarına kendilerini ifade edebilmeleri için sunduğu bu olanakların başarısı için, bu uygulamaları yaparken karışık mesajlar verilmemesi gerekir. Diğer taraftan çalışanlar için birçok yetkilendirme programı ve gelişme planları tasarlanırken, diğer yandan aynı çalışanların örgütteki yöneticilerin fikirlerine ayak uydurmaları beklenir (Özgen ve Sürgevil, 2009: 322).

Yöneticiler demokratik bir ortam oluşturmaya çalışsa bile, negatif geri bildirimde bulunma ya da farklı görüş̧leri dile getirme konusunda çalışanlar sessiz kalmayı tercih edebilmektedir. Çalışanların kişisel özelliklerini ve değer yargılarını değiştirmek zor olsa da yöneticiler, çalışanları sessizliğe iten nedenleri ortadan kaldırmak için çaba sarfedebilirler ve çalışanların da aktif bir biçimde yer aldığı bir resmi iletişim kanalı oluşturabilirler. Açıkça konuşmayı tercih edenlerin "şikayetçi" ya da "sorun çıkarıcı" olarak algılanmadığı formel bir sistem kurulabilir (Çakıcı, 2007: 160). 


\section{SONUÇ}

Örgütsel sessizlik, bir konu veya sorun karşısında, çalışanların itaat, korku ve işbirliği güdüleri ile hareket ederek, bilgi, duygu ve düşüncelerini kasıtlı olarak paylaşmamalarıdır. Örgüt içinde karşılaşılan sorunlar karşısında, örgüt üyelerinin verdiği tepkilerin başında, içinde birçok duyguyu da barındıran sessizlik davranışı gelmektedir. Örgüt üyeleri, söylediklerinin bir fark yaratmayacağını düşünmeleri nedeniyle kabullenici sessizliği, kendilerini koruma amacıyla savunma amaçlı sessizliği ya da örgütü koruma amacıyla koruma amaçlı (prososyal) sessizliği tercih edebilmektedir.

Örgüt üyelerinin sessizliği tercih etmesinin temelinde birçok örgütsel ve bireysel neden bulunmaktadır. Bu örgütsel nedenlerin başında, yöneticilerin olumsuz geri bildirim almaktan korkmaları yer almaktadır. Yöneticilerin çalışanlar hakkındaki olumsuz görüşleri ve çalışanlara güvenmemeleri de sık karşılaşılan örgütsel sessizlik nedenlerdendir. Kararların genellikle üst yönetim tarafından alınması, örgüt üyelerinin fikir ve görüşlerine önem verilmemesi, çalışanlar arasında ayrım yapılması, yöneticilerden korkulması ve onlara güvenilmemesi de çalışanların sessizlik tercihlerini şekillendirmekte ve çalışanlar arasında sessizlik davranışı sık görülen bir davranış haline gelmektedir. Ayrıca, örgüt üyelerinin fikirlerine önem vermeyen örgüt yapısı nedeniyle çalışanların algılarındaki bozulmalarda sessizliğe neden olmaktadır. Bu örgütsel nedenlerin yanı sıra; yaş, cinsiyet, eğitim düzeyi, deneyim ya da psikolojik yıldırma (mobbing) algısı gibi bireysel faktörler de örgüt üyelerinin sessizlik tercihini etkilemektedir. Örgütsel ve bireysel nedenler, örgüt içerisinde sessizlik ikliminin hâkim olmasına neden olarak, çalışanların bilgi, duygu ve düşüncelerini açıkça ifade etmelerine engel olmaktadir.

Bir örgütü çalışanlarından bağımsız olarak düşünmek mümkün değildir. Bu nedenle örgüt ile çalışanlar arasındaki uyumu sağlayacak davranış biçimlerinin geliştirilebilmesi için, çalışanların her koşulda kendilerini ifade edebilecekleri bir örgüt kültürünün oluşturulması gerekmektedir. Örgütsel sessizliğin, örgüt içinde yaygın bir kültür haline gelmesi örgütler için büyük tehlike arz etmekte, yeniliklerin ve değişimin önünde ciddi bir engel oluşturmaktadır. Bilgiyi paylaşma, konuşma ve geri bildirim sunma konusundaki isteksizlik, çalışanların verimliliğini, motivasyonunu, örgüte duyduğu güven ve bağlllı̆̆ olumsuz olarak etkileme potansiyeline sahiptir. Ayrıca, çalışanların sahip olduğu bilgi ve fikirlerini kendine saklanması, örgütsel karar verme, değişim, hata düzeltme-geliştirme ve yenilik süreçlerini de zayıflatabilecektir. Merkezi karar verme, yukarı yönlü geribildirim mekanizmalarının olmaması, çalışanların savunma tepkileri gibi örgütsel sessizliğin oluşması için elverişli yapısal ve yönetsel faktörler olması, sessizliği teşvik eden örgüt kültürünün oluşmasına neden olmaktadır. Örgütsel sessizliğe katkıda bulunan yönetsel inançlar ve hiyerarşik seviyelerin çok olduğu örgütlerde sessizlik daha yaygın olacaktır ve örgüt içinde güçlü bir sessizlik ikliminin gelişme olasılığını artıracaktır. Bu nedenle, yöneticilerin örgütsel sessizlik nedenlerini ortadan kaldırarak çalışanların bilgi, duygu ve düşüncelerini açıkça ifade edebilecekleri bir örgüt yapısı oluşturmaları oldukça önemlidir. Örgütsel sessizliğin önüne geçilmesiyle örgütsel bağlılığın yanı sıra kaynakların daha etkin ve verimli kullanılmasını sağlamak mümkün hale gelecektir.

Örgütlerin, çalışanlarının görüş, fikir ve geri bildirimlerini ifade etmekten alıkoyma eğilimleri, çalışanların istenmeyen tepkiler göstermesine ve istenmeyen sonuçlar ortaya çıkmasına neden olmaktadır. Hızla değişen çevrelerde, üst yönetimin ihtiyaç duydukları bilgilere doğru ve hızlı bir biçimde ulaşmaları oldukça önemlidir. Çalışanların özgüvenlerinin arttırılması, 
kendilerini önemli ve örgüte ait hissetmelerini sağlamak örgütsel sessizlik ile mücadele etmede önemli bir adımdır. Örgütteki sessizliğin memnuniyet göstergesi olarak algılanmasının önüne geçilerek, yöneticilerin kritik önem taşıyan konularda çalışanların da fikir ve görüşlerine başvurmaları, çalışanları fikir ve görüşlerini açıça ifade etmeleri yönünde cesaretlendirmeleri gerekmektedir. Böylelikle, örgütsel sessizliğin, örgütün değişimi ve gelişimine engel olmasının önüne geçilebilecektir. Yöneticilerin çalışanlar ile arasındaki bağı güçlendirmeleri, çalışanların her durumda kendilerini ifade edebilecekleri bir örgüt kültürü oluşturulması ve çalışanların yöneticilere güveninin sağlanması ile örgütsel sessizliğin önüne geçilmesi tüm toplumun yararına olacaktır.

\section{Kaynakça}

Bowen, Frances, Blackmon, Kate (2003), Spirals of Silence: The Dynamic Effects of Diversity on Organizational Voice, Journal of Management Studies (40:6): 1393-1417.

Brinsfield, Chad T. (2009), Employee Silence: Investigation of Dimensionality, Development of Measures, and Examinatıon of Related Factors Dissertation, Yayımlanmamış Doktora Tezi, Ohio State University, Ohio.

Brinsfield, Chad T., Edwards, Marissa S., Greenberg, Jerald (2009), "Voice and Silence in Organizations Historical Reviev and Current Conceptualizations", içinde J. Greenberg ve M.S. Edwards (Ed.), Voice and Silence in Organizations,(ss. 3-33), UK: Emerald Group Publishing Limited.

Çakıcı, Ayşehan (2007), Örgütlerde Sessizlik: Sessizliğin Teorik Temelleri ve Dinamikleri, Çukurova Üniversitesi Sosyal Bilimler Enstitüsü Dergisi, 16 (1): 145-162.

Çakıcı, Ayşehan (2010), Örgütlerde İşgören Sessizliği: Neden Sessiz Kalmayı Tercih Ediyoruz?, 1. Bask1, Ankara: Detay Yayınc1lık.

Demir, Mahmut, Demir, Şirvan Şen (2012), Yükseköğretim Kurumlarında Örgütsel Sessizlik: Turizm Lisans Eğitimi Kurumları Örneği, Milli Ĕ̆itim Dergisi (193): 184-199.

Durak, İbrahim (2012), Korku kültürü ve Örgütsel Sessizlik. Bursa: Ekin Yayınevi.

Eroğlu, Ahmet Hüsrev, Adıgüzel, Orhan, Öztürk, Umut Can (2011), Sessizlik Girdabı ve Bağll1ık İkilemi: İşgören Sessizliği ile Örgütsel Bağlılık İlişkisi ve Bir Araştırma, Süleyman Demirel Üniversitesi İktisadi ve İdari Bilimler Fakültesi Dergisi, 16(2): 97-124.

Gül, Hasan, Özcan, Nazlı (2011), Mobbing ve Örgütsel Sessizlik Arasındaki İlişkiler: Karaman İl Özel İdaresinde Görgül Bir Çalışma, KSÜ İIBF Dergisi, 1(2): 107-135.

Kahveci Gökhan, Demirtaş, Zülfü (2013), Okul Yöneticisi ve Öğretmenlerin Örgütsel Sessizlik Alg1ları, Eğitim ve Bilim, 38(167): 50-64.

Lustenberger, Donald E., Willıams, Kipling D. (2009), Ostracisim in Organization, Greenberg ve Edwards (Editör), Voice and Silence in Organizations, (245-272), United Kingdom: Emerald Group Publishing.

Milliken, Frances J., Morrison, Elizabeth Wolfe (2003), Shades of Silence: Emerging Themes and Future Directions for Research on Silence in Organizations, Journal of Management Studies (40)6: 1563 - 1568. 
Morrison, Elizabeth Wolfe, Milliken, Frances J. (2000), Organizational Silence: A Barrier To Change And Development In A Pluralistic Academy Of Management, The Academy Of Management Review, (25)4: 706-725.

Özgen, Işıl, Sürgevil, Olca (2009), “Örgütsel Sessizlik Olgusu ve Turizm İşletmeleri Açısından Değerlendirilmesi”, içinde : Z. Sabuncuoğlu (Ed.), Turizm İşletmelerinde Örgütsel Davranış, (ss. 303-328), Bursa: MKM Yayıncilık.

Öztürk, Umut Can, Cevher, Ezgi (2016), Sessizlikteki Mobbing: Mobbing ve Örgütsel Sessizlik Arasındaki İlişki, KMÜ Sosyal ve Ekonomik Araştırmalar Dergisi, 18 (30): 71 - 80.

Pinder, Craig C., Harlos, Karen P. (2001), Employee Silence: Quiescence and Acquiescence As Responses to Perceived Injustice, Research in Personnel and Human Resources Management, (20): 331-369.

Rosen, Sidney, Tesser, Abraham (1970), On Reluctance to Communicate Undesirable Information: The MUM effect, Sociometry, 33(3): 253-263.

Sümer, Hayriye Canan (2007), “Çok Kaynaklı Geri Bildirim ve Kültür: Kritik Bir Bakış”, içinde R. Erdem ve C.Ş. Çukur (Ed.), Kültürel Bă̆lamda Yönetsel-Örgütsel Davranış, (ss. 347-385), 1. Baskı, Ankara: Türk Psikologlar Derneği Yayınları.

Tangirala, Subrahmaniam, Ramanujam, Rangaraj (2008), Employee Silence in Critical Work Issues: The Cross Level Effects of Procedural Justice Climate, Personnel Psychology, (61): 3768.

Taşkıran, Erkan (2011), Liderlik ve Örgütsel Sessizlik Arasındaki Etkileşim: Örgütsel Adaletin Rolü, 1. Baskı, İstanbul: Beta Basım.

Tayfun, Ahmet, IŞIN, Alper, Küçükergin, Kemal Gürkan (2016), Örgütsel Sessizliğin İş Tatmini ve Örgütsel Bağlllık Üzerindeki Belirleyici Rolü, Gazi Üniversitesi Turizm Fakültesi Dergisi, (1): 35-49.

Uysal Irak, Doruk (2010) “Örgütlerde cinsiyet ayrımcllı̆ı ve örgütsel sonuçlar uzerindeki etkileri", içinde R.Erdem (Ed.), Yönetim ve Örgüt Açısından Kayırmacılık, (ss.179-202), 1. Baskı, İstanbul: Beta Yayınları.

Vakola, Maria, Bouradas, Dimitris (2005), Antecedents and Consequences of Organisational Silence: An Empirical Investigation, Employee Relations, (27)5: 441-458.

Van Dyne. Linn, Ang, Soon, Botero, Isabel C. (2003), Conceptualizing Employee Silence and Employee Voice as Multidimensional Constructs, Journal of Management Studies, (40)6: 13591392.

Wasti, S. Arzu (2000), “Örgütsel Bağl1lı̆̆1 Belirleyen Evrensel ve Külütrel Etmenler: Türk Kültürüne Bir Bakış”, içinde Z. Aycan (Ed.), Türkiye'de Yönetim, Liderlik ve İnsan Kaynakları Uygulamaları, (ss. 201-224), 1. Baskı, Ankara: Türk Psikologlar Derneği Yayınları.

Williams, Kipling D. (2007). Ostracism, Annual Review of Psychology, 58, 425-452.

Zerenler, Muammer (2011), “Örgütsel Sessizlik”, içinde A. Bedük (Ed.), “Örgüt Psikolojisi Yeni Yaklaşımlar, Güncel Konular", (ss.143-166), 1. Baskı, İstanbul: Atlas Akademi. 